\title{
How to Manage your Postgraduate Course
}




\section{Visit our online Study Skills resource at www.skills4study.com}

\section{Palgrave Study Guides}

A Handbook of Writing for Engineers Joan van Emden Authoring a PhD Patrick Dunleavy

Career Skills David Littleford, John Halstead and Charles Mulraine

e-Learning Skills Alan Clarke

Effective Communication for Arts and Humanities Students

Joan van Emden and Lucinda Becker

Effective Communication for Science and Technology Joan van Emden

The Foundations of Research Jonathan Grix

The Good Supervisor Gina Wisker

How to Manage your Arts, Humanities and Social Science Degree Lucinda Becker

How to Manage your Distance and Open Learning Course Lucinda Becker

How to Manage your Postgraduate Course Lucinda Becker

How to Manage your Science and Technology Degree Lucinda Becker and David Price

How to Study Foreign Languages Marilyn Lewis

How to Write Better Essays Bryan Greetham

Making Sense of Statistics Michael Wood

The Mature Student's Guide to Writing Jean Rose

The Postgraduate Research Handbook Gina Wisker

Professional Writing Sky Marsen

Research Using IT Hilary Coombes

Skills for Success Stella Cottrell

Presentation Skills for Students Joan van Emden and Lucinda Becker

The Student's Guide to Writing John Peck and Martin Coyle

The Study Skills Handbook (second edition) Stella Cottrell

Study Skills for Speakers of English as a Second Language

Marilyn Lewis and Hayo Reinders

Studying the Built Environment Marion Temple

Studying Economics Brian Atkinson and Susan Johns

Studying History (second edition) Jeremy Black and Donald M. MacRaild

Studying Mathematics and its Applications Peter Kahn

Studying Modern Drama (second edition) Kenneth Pickering

Studying Physics David Sands

Studying Psychology Andrew Stevenson

Teaching Study Skills and Supporting Learning Stella Cottrell

Work Placements - A Survival Guide for Students Christine Fanthome 


\section{How to Manage your Postgraduate Course}

Lucinda Becker 


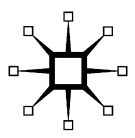

(C) Lucinda Becker 2004

All rights reserved. No reproduction, copy or transmission of this publication may be made without written permission.

No paragraph of this publication may be reproduced, copied or transmitted save with written permission or in accordance with the provisions of the Copyright, Designs and Patents Act 1988, or under the terms of any licence permitting limited copying issued by the Copyright Licensing Agency, 90 Tottenham Court Road, London W1T 4LP.

Any person who does any unauthorised act in relation to this publication may be liable to criminal prosecution and civil claims for damages.

The author has asserted her right to be identified as the author of this work in accordance with the Copyright, Designs and Patents Act 1988.

First published 2004 by

PALGRAVE MACMILLAN

Houndmills, Basingstoke, Hampshire RG21 6XS and

175 Fifth Avenue, New York, N.Y. 10010

Companies and representatives throughout the world

PALGRAVE MACMILLAN is the global academic imprint of the Palgrave Macmillan division of St. Martin's Press, LLC and of Palgrave Macmillan Ltd. Macmillan ${ }^{\circledR}$ is a registered trademark in the United States, United Kingdom and other countries. Palgrave is a registered trademark in the European Union and other countries.

ISBN 978-1-4039-1656-3 ISBN 978-0-230-80192-9 (eBook)

DOI 10.1007/978-0-230-80192-9

This book is printed on paper suitable for recycling and made from fully managed and sustained forest sources.

$\begin{array}{llllllllll}10 & 9 & 8 & 7 & 6 & 5 & 4 & 3 & 2 & 1\end{array}$

$\begin{array}{llllllllll}13 & 12 & 11 & 10 & 09 & 08 & 07 & 06 & 05 & 04\end{array}$ 


\section{Contents}

Acknowledgements

1 Introduction 1

The purpose of this book 1

Taking an overview of your course 3

2 Choosing and Beginning your Postgraduate Course

Becoming a postgraduate student 9

Assessment $\quad 15$

3 Studying Opportunities 24

Seminars $\quad 25$

Lectures $\quad 27$

Visiting speakers $\quad 28$

Conferences $\quad 30$

Discussion groups $\quad 32$

Tutorials 33

E-learning $\quad 34$

Placements $\quad 36$

Work-based projects $\quad 38$

4 Your Skills Base $\quad 40$

$\begin{array}{ll}\text { Your range of skills } & 41\end{array}$

Postgraduate skills development $\quad 42$

$\begin{array}{ll}\text { Reading productively } & 42\end{array}$

$\begin{array}{ll}\text { Articulating your ideas } & 47\end{array}$

Reporting your results in writing $\quad 50$

$\begin{array}{ll}\text { Writing persuasively } & 51\end{array}$

Presenting your work orally 53

Problem-solving 54

Thinking creatively $\quad 55$

Planning effectively $\quad 58$

Analysing and developing your skills base 59 
5 Working with your Supervisor 64

How to begin 65

What you can expect from your supervisor 68

Developing your relationship $\quad 73$

Life from your supervisor's point of view 77

6 Managing your Course 81

Taking control $\quad 82$

Making connections $\quad 86$

Keeping on track 89

$\begin{array}{ll}\text { Time management } & 92\end{array}$

7 What if Things go Wrong? 99

8 Teamwork and Networking 117

Analysing a team 118

Identifying your teams $\quad 123$

9 Presenting your Ideas 132

Research presentations 133

Seminar presentations $\quad 137$

Conference papers 140

Publication 143

10 Writing up your Research 148

Timing 149

Planning $\quad 152$

Word count 159

Draft and rewrites 162

Creating a bibliography 163

Style 165

11 Moving on from your Postgraduate Course 170

Focusing on the future 170

Breaking into the career market 173

$\begin{array}{ll}\text { Creating a CV } & 177\end{array}$

An academic career 181

Achieving success 185 


\section{Acknowledgements}

I would like to thank Paul McColm for making this book so much more effective than it would otherwise have been. I would also like to thank Kate Howlett, who worked so hard to widen the book's appeal. I am grateful to Michael C. Milam for giving me so much support from across the Atlantic and, as always, Felicity and Anastasia Becker made light work of proofreading and ensured that the index is as comprehensive and accurate as possible. 